\title{
Основные задачи селекции сливы на Алтае
}

Гарапов Д.С., н.с.

Федеральный Алтайский научный центр агробиотехнологий, Барнаул, Россия. e-mail:prunus@inbox.ru

В результате многолетней селекиионной работы по повымению адаптивного потенциила сливы на Алтае созданы сорта и элитные формы на основе межвидовой гибридизачии. От скрещчивания сортов и форм алычи с местныли сортами сливы уссурийской получены сорта и перспективные гибриды с плотной мякотью плодов, среднеустойчивые к выпреванию, устойчивые к плодожорке и монилиозу. Показана возможность выделения невыпреваюших клоновых подвоев сливы на основе межвидовых гибридов терна.

Ключевые слова: слива уссурийская, алыча, сорт, терн, межвидовые гибриды, подвой.

\section{The main objects of plum breeding in Altai}

Garapov Denis Sergeevich, Federal Altai Scientific Centre of Agro Biotechnologies, Barnaul, Russia, e-mail: prunus@inbox.ru

Long-term breeding for plum adaptation to Siberian conditions resulted in new cultivars and elites originated from interspecific hybridization. Crossing Prunus cerasifera forms and cvs. with P. ussuriensis local cvs. made it possible to have cultivars and promising hybrids with improved fruit traits (firmness), moderate tolerance to asphyxiation, disease and insect resistance. Non-asphyxiating rootstock for plum can be selected on the basis of P. spinosa interspecific hybrids.

Key words: Ussurian plum, cherry plum, cultivar, blackthorn, interspecific hybrids, rootstock.

В суровых климатических условиях Сибири культура сливы является любительской, как и другие плодовые культуры [1]. Слабое распространение сливы в Западной Сибири, чем в Западной Сибири связано с тем, что в многоснежных районах растения ежегодно повреждаются выпреванием и по разным причинам плодоносят нерегулярно [2]. Но и в более благоприятных климатических зонах Сибири сливовые сады не являются товарными. Отчасти это объясняется дефицитом сортов с соответствующим качеством плодов (транспортабельность, крупноплодность). Такие же требования к сортам предъявляет любительский сектор. Основным направлением в улучшении сортимента сливы в Сибири, как и во всех зонах плодоводства России, является создание продуктивных, адаптированных к местным условиям сортов с высокими товарными качествами плодов [3].

В Алтайском научном центре агробиотехнологий накоплен и изучен 84 
богатый фонд доноров и источников селекционно-значимых признаков $[4,5]$. Встает вопрос их сохранения и рационального использования. В связи с этим, цель настоящей работы - определить задачи селекции сливы на Алтае.

Систематическая работа с культурой сливы на Алтае начата с 1935 г. Работа ведется в двух природно-климатических зонах - среднегорье Алтая (с. Чемал) и лесостепная зона (г. Барнаул). К настоящему времени селекционерами В.С. Путовым, И.А. Пучкиным и М.Н. Матюниным выведены относительно адаптированные сорта [6, 7]. Все они получены на основе сливы уссурийской (Prunus ussuriensis) и являются ее гибридами со сливой китайской (P. salicina). Некоторые сорта представляют собой межвидовые гибриды с участием алычи (P. cerasifera) и сливы американской (P. americana). Несмотря на использование межвидовой гибридизации, основные недостатки, унаследованные от сливы уссурийской (слабая зимостойкость плодовых почек, раннее цветение, неустойчивость к выпреванию), не преодолены. В последние годы отмечен прогресс в выведении устойчивых к выпреванию сортов. Получены первые сибирские сорта гибридной алычи или сливы русской (P. rossica) - Дака, Цыганочка, элитная форма Дудука [7]. Изза недостаточной морозоустойчивости плодовых почек, периодичность плодоношения у них выражена сильнее, чем у китайско-уссурийской сливы. Тем не менее, некоторые формы гибридной алычи по урожайности не уступают лучшим сортам сливы (табл. 1).

Таблица 1 - Урожайность сортообразцов сливы и гибридной алычи в саду первичного изучения, г. Барнаул, посадка осени 2007, 2008 гг., схема $5 \times 2$ м

\begin{tabular}{|c|c|c|c|c|c|c|c|c|}
\hline \multirow{3}{*}{ Сортообразец } & \multicolumn{7}{|c|}{ Урожайность, т/га } & \multirow{3}{*}{$\begin{array}{c}\text { Состояние } \\
\text { к } 2019 \text { г., } \\
\text { балл }\end{array}$} \\
\hline & \multicolumn{7}{|c|}{ Годы } & \\
\hline & 2013 & 2015 & 2016 & 2017 & 2018 & 2019 & $\begin{array}{l}2013- \\
2019\end{array}$ & \\
\hline \multicolumn{9}{|c|}{ Слива } \\
\hline $\begin{array}{l}\text { Алтайская } \\
\text { юбилейная }\end{array}$ & 0,2 & 4,7 & 1,8 & 6,2 & 4,5 & 4,8 & 3,7 & 3,5 \\
\hline Узюк & 2,2 & 8,5 & 6,1 & 2,5 & 1,3 & 5,3 & 4,3 & 3,3 \\
\hline \multicolumn{9}{|c|}{ Гибридная альча } \\
\hline ГА 12-60 & 0,3 & 0,5 & 5,7 & 7,8 & 4,7 & 8,0 & 4,5 & 3,8 \\
\hline Дудука & 0 & 1,8 & 1,4 & 6,0 & 3,3 & 4,5 & 2,8 & 3,1 \\
\hline $\mathrm{HCP}_{05}$ & 0,4 & 2,3 & 3,8 & $\mathrm{~F}_{\phi}<\mathrm{F}_{\mathrm{T}}$ & $\mathrm{F}_{\phi}<\mathrm{F}_{\mathrm{T}}$ & $\mathrm{F}_{\phi}<\mathrm{F}_{\mathrm{T}}$ & $\mathrm{F}_{\phi}<\mathrm{F}_{\mathrm{T}}$ & 0,5 \\
\hline
\end{tabular}

Алыча привлечена в селекцию для создания устойчивых к выпреванию сортов сливы. При скрещиваниях сливы уссурийской с алычой происходит и снижение морозостойкости гибридов. Работа с алычой начиналась с мелкоплодных форм - гибрида II-31 (армянская алыча х слива уссурийская), алычи согдийской (P. sogdiana), алычи Писсарда из барнаульского дендрария. Среди гибридов $\mathrm{F}_{1}$ наибольшую зимостойкость 
и устойчивость к выпреванию показали сеянцы гибридной алычи II-31, в том числе отборная форма ГА 12-60, и сеянцы алычи согдийской. В Барнауле зимостойкие гибриды получены с участием сорта грузинской алычи Красное знамя. Гибриды $\mathrm{F}_{1}$, полученные от свободного опыления алычи Писсарда зимостойкими сортообразцами сливы уссурийской (5-6, Краснощекая, Пониклая и др.), были недостаточно зимостойкими, но выделены крупноплодные формы с высокими вкусовыми (9-269-14, 9-28414) и консервными качествами (9-248-14). При повторном скрещивании гибридов $\mathrm{F}_{1}$ со сливой уссурийской морозостойкость в $\mathrm{F}_{2}$ повысилась, но устойчивость к выпреванию снизилась или осталась на прежнем уровне. Среднезимостойкая форма Дудука получена от скрещивания слабозимостойкого сорта сливы Красномясая с гибридами $\mathrm{F}_{1}$ алыча Писсарда $\times$ слива уссурийская [7].

Для создания сортов с высокими товарными качествами плодов привлечен донор признака плотной (хрящеватой) мякоти плодов - сорт армянской алычи Аштаракская 2. Наиболее зимостойкие формы с участием этого сорта получены от повторного скрещивания гибридов $\mathrm{F}_{1}$ с со сливой уссурийской, где в каждом поколении участвовали высокозимостойкие сорта сливы Желтая Хопты, Катунская, Краснощекая, Пирамидальная, Пониклая. Формы, выделенные среди гибридов $\mathrm{F}_{1}$ (Караташ) и $\mathrm{F}_{2}$ (Ида, Лира), проходят испытание на Шушенском госсортоучастке. Удовлетворительную зимостойкость в Барнауле показала элитная формаОсенняя черная селекции Н.М. Матюнина. В отличие от первых сортов гибридной алычи, у этих форм появились новые признаки - плотная консистенция мякоти, транспортабельность плодов [7]. Не менее важными признаками, приобретенными от алычи, являются устойчивость к плодожорке, к поражению плодов монилиозом и устойчивость к осыпанию плодов (Дака, Цыганочка).

Алыча значительно обогатила алтайский генофонд сливы. При этом задействована лишь небольшая часть кавказского и среднеазиатского генофонда алычи, обладающего значительным полиморфизмом [8], в том числе за счет интрогрессии некоторых генов от микровишни мелкоплодной (P. microcarpa), культурных сортов сливы китайской, персика и абрикоса [9]. Целесообразно скрещивать гибриды с участием различных разновидностей алычи, как между собой, так и с различными сортами сливы [10].

В Чемале созданы гибриды диплоидных слив с терном (P. spinosa), терносливой (P. insititia) и сливой домашней (P. domestica). Полиплоидные сливы привлечены в селекцию за устойчивость к выпреванию, длительный зимний покой плодовых почек и позднее цветение. Объединение геномов полиплоидных и диплоидных видов затруднено, гибриды слабоплодовиты, 
но лучшие из них значительно превосходят исходные виды по адаптивности (табл. 2).

Таблища 2 - Изучение сливы, терносливы и межвидовых гибридов терна в коллекции, г. Барнаул, среднее за 2015-2019 гг.

\begin{tabular}{|c|c|c|c|c|}
\hline Сортообразец & 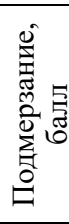 & 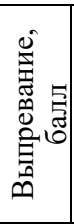 & 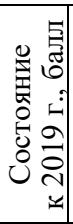 & 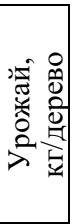 \\
\hline \multicolumn{5}{|l|}{ Слива (посадка осени 2011 г.) } \\
\hline $\begin{array}{l}\text { Алтайская юбилейная } \\
\text { (прививка на штамб невыпревающего подвоя 61-2) }\end{array}$ & 1,0 & 0,3 & 3,7 & 2,6 \\
\hline \multicolumn{5}{|l|}{ Тернослива (посадка осени 2011 г.) } \\
\hline 18-119 (сеянец Терна № 3) & 2,1 & 0,7 & 2,0 & 1,5 \\
\hline \multicolumn{5}{|c|}{$\begin{array}{c}\text { Межвидовые гибриды терна } \\
\text { (прививка весны 2010-2012 гг., посадка осени 2008-2010 гг.) }\end{array}$} \\
\hline 31-60 [16-9 (Тока × терн) $\times$ Тернослива хабаровская] & 0,9 & 0,3 & 5,0 & 0 \\
\hline $\begin{array}{l}\text { ТСГ № } 1 \text { [сеянец Терносливы хабаровской } \\
\text { (слива уссурийская × тернослива)] }\end{array}$ & 1,0 & 0,6 & 4,5 & 0 \\
\hline 10-42-00 [Тернослива хабаровская $\times($ Пчелка $\times$ терн $)]$ & 0,8 & 0,2 & 4,5 & 0,1 \\
\hline $\begin{array}{l}\text { 16-1-00 [сеянец гибрида 4-60 } \\
\text { (слива уссурийская × тернослива)] }\end{array}$ & 0,8 & 1,0 & 4,3 & 1,2 \\
\hline Г 12-3 [(слива уссурийская × алыча) × Тернослива хабаровская] & 1,1 & 0,9 & 4,0 & 0 \\
\hline ГЭС 6-76 [сеянец гибрида № 53 (Сапа × терн крупноплодный)] & 1,5 & 0,6 & 4,0 & 0 \\
\hline
\end{tabular}

В Чемале имеется более 500 сеянцев терновых гибридов в селекционных садах, в Барнауле - 135 сеянцев и 60 сортообразцов в коллекции. Данный фонд межвидовых гибридов терна следует использовать для выделения клоновых подвоев сливы, устойчивых к выпреванию. В Чемале и Барнауле проводится оценка способности терновых гибридов к размножению зелеными черенками. Проблема заключается в том, что терн и тернослива не обладают такой способностью. Донором этого признака является микровишня низкая (P. pumila) и ее гибриды с диплоидными сливами (сливо-вишневые гибриды). Высокую окореняемость черенков имеют и многие сортообразцы типичной алычи [11].

Таким образом, основными задачами по культуре сливы являются:

- сохранение и расширение генофонда донорами и источниками селекционно-значимых признаков;

- создание сортов с повышенной адаптацией (высокая зимостойкость 
плодовых почек, позднее цветение, устойчивость к выпреванию) и высокими товарными качествами плодов (транспортабельность, крупноплодность);

- выделение и создание клоновых подвоев сливы, устойчивых к выпреванию, зимостойких, пригодных для использования в качестве штамбообразователей по принятой технологии выращивания саженцев, совместимые с большинством сортов сливы.

\section{Список литературы}

1. Усенко В.И. Состояние и перспективы развития промышленного садоводства в Сибири // Садоводство и виноградарство. - 2009. - № 5. - С. 17-19.

2. Программа работ селекцентра Научно-исследовательского института садоводства Сибири имени М.А. Лисавенко до 2030 г.: выпуск 3 / Под ред. В.И. Усенко, И.А. Пучкина; ГНУ НИИСС Россельхозакадемии. - Новосибирск: РИЦ СибНСХБ Россельхозакадемии, 2011. - 335 с.

3. Помология. Том ІІІ. Косточковые культуры / под ред. Е.Н. Седова. - Орел: ВНИИСПК, 2008. - 592 с.

4. Каталог паспортов доноров и источников селекционно-значимых признаков северных видов сливы, вишни и черемухи / составители Г.В. Еремин, И.С. Чепинога, О.В. Еремина, ГНУ Крымская ОСС; М.Н. Матюнин, НИИСС; В.С. Симагин, ЦСБС СО РАН; В.П. Царенко, Н.А. Царенко, Дальневосточная ОС ВИР; под ред. Г.В. Еремина. - Крымск: ГНУ Крымская ОСС, 2010. - 100 с.

5. Мочалова О.В. Цитоэмбриология и селекция отдаленных гибридов и полиплоидов косточковых растений на Алтае / О.В. Мочалова, М.Н. Матюнин; РАСХН, Сибирское отделение, НИИСС им. М.А. Лисавенко. - Новосибирск: ГУП РПО СО РАСХН, 2002. - 232 c.

6. Помология. Сибирские сорта плодовых и ягодных культур ХХ столетия / РАСХН, Сиб. отд-ние, ГНУ НИИСС им. М.А. Лисавенко; под общ. ред. И.П. Калининой. - Новосибирск: Юпитер, 2005. - 568 с.

7. Матюнин М.Н. Биологические особенности и селекция косточковых культур в Горном Алтае / М.Н. Матюнин; ФГУП «Горно-Алтайское», Министерство сельского хозяйства Республики Алтай. - Горно-Алтайск, 2016. - 344 с.

8. Horvath A. Genetic diversity and relationships among Prunus cerasifera (cherry plum) clones / A. Horvath, H. Christmann, F. Laigret // Botany. - 2008. - Vol. 86. - P. 3011-3018.

9. Еремин Г.В. Отдаленная гибридизация косточковых плодовых растений / Г.В. Еремин. - М.: Агропромиздат, 1985. - 280 с.

10. Еремин Г.В. Алыча и слива русская // Современные методологические аспекты организации селекционного процесса в садоводстве и виноградарстве / Под общ. ред. акад. РАСХН Г.В. Еремина. - Краснодар: СКЗНИИСиВ, 2012. - С. 346354.

11. Гнездилов Ю.А. Размножение косточковых культур зелеными черенками / Ю.А. Гнездилов, С.В. Симакина // Труды по прикладной ботанике, генетике и селекции / ВИР. - Л., 1976. - Т. 56. - Вып. 2. - С. 68-79. 